\title{
THE EFFECTIVENESS OF CARBON NEUTRALIZATION: FUNDAMENTAL RIGHT TO DEVELOPMENT
}

\section{A EFETIVAÇÃO DA NEUTRALIZAÇÃO DE CARBONO: DIREITO FUNDAMENTAL AO DESENVOLVIMENTO}

\begin{abstract}
Jussara Suzi Assis Borges Nasser Ferreira
Doutora em Direito das Relações Sociais pela PUC-SP. Advogada sócia-fundadora do Escritório Borges Ferreira. Professora Permanente do Programa de Doutorado e Mestrado em Direito na Universidade de Marília - UNIMAR e do Programa de Mestrado em Direito Processual e Cidadania da Universidade Paranaense - UNIPAR. Professora da Fundação Escola Superior do Ministério Público do Mato Grosso - FESMP. Membro Efetivo do CONPEDI, IBDFAM e IBDCivil. Autora de obras e artigos jurídicos.

E-mail: jussara@bflaw.adv.br
\end{abstract}

André Luís Cateli Rosa

Assessor Jurídico do Banco do Brasil S/A. Advogado e Administrador. Doutorando em Direito pela Universidade de Marília. Mestre em Direito pelo Centro Universitário Eurípides de Marília. Professor das Faculdades Integradas de Ourinhos - FIO. Autor de livros e artigos. Membro da Associação Brasileira de Direito e Economia. E-mail: andrerosaadv@yahoo.com.br

Recebido em: 04/10/2018

Aprovado em: 14/01/2019

\begin{abstract}
In this study, the problem of carbon neutralization is addressed due to the greenhouse effect, including the international mechanisms involved, in order to demonstrate the possibility of implementation of rights through an understanding of the developmental theory as freedom, together with readings about the dynamogenic process and social education. The legal responsibilities used worldwide to deal with the global warming issue, indicating carbon neutralization as one of the possible solutions, is supported by the Kyoto Protocol and the Paris Agreement regarding the clean development. The potential conditions are discussed in favor of the fundamental right to an ecologically balanced environment. This investigation adopts the critical analytical methodology, addressing in a relational way the developmental theory as freedom, the normative production, and education, which are essential for individuals to construct the values of society, in order to achieve an integral developmental purpose. Finally, this work shows that the developmental theory as freedom presents solid foundations leading us to believe that its application might help the world to find solutions that meet the reduction targets of the greenhouse effect gases, ensuring, therefore, proper conditions to future generations, through a dynamogenic process that assures an integral, financially feasible, socially fair and environmentally responsible development.

Keywords: Carbon Neutralization. Ecologically balanced environment. Development as freedom. Integral Development.
\end{abstract}

RESUMO: No presente estudo, aborda-se o problema da neutralização de carbono em decorrência do efeito estufa, abrangendo os mecanismos internacionais para tal fim, com o objetivo de demonstrar a possibilidade da efetivação de direitos por meio da teoria do desenvolvimento como liberdade, acrescida da leitura referente ao processo de dynamogenesis e educação para o social. As tutelas jurídicas utilizadas mundialmente com o propósito de enfrentar a questão do aquecimento global indicando como um dos meios possíveis a neutralização do carbono, têm amparo no Protocolo de Quioto e no Acordo de Paris com referência ao desenvolvimento limpo. São referidas as condições de possibilidade em favor do direito fundamental ao meio ambiente ecologicamente equilibrado. A investigação adota a metódica axiológica, analítica-crítica, abordando de forma relacional a teoria do desenvolvimento como liberdade, a produção

Revista de Direito Brasileira | São Paulo, SP | v. 21 | n. 8 | p. $22-42$ |Set./Dez. 2018 
normativa e a educação, que são essenciais para que os indivíduos participem da formação dos valores da sociedade, com vistas à concretização do propósito desenvolvimentista integral. Por fim verifica-se que a teoria do desenvolvimento como liberdade possui fundamentos sólidos para fazer crer que sua aplicação pode auxiliar na busca de soluções para alcançar as metas de redução dos gases do efeito estufa, assegurando, assim, condições dignas de vida às futuras gerações, por meio de um processo de dinamogenesis que assegure o desenvolvimento integral, financeiramente viável, socialmente justo e ambientalmente responsável.

Palavras-chave: Neutralização de carbono. Meio ambiente ecologicamente equilibrado. Desenvolvimento como liberdade. Desenvolvimento integral.

SUMMARY: Introduction. 1 The greenhouse effect and global warming. 2 carbon neutralization: fundamental right to development. 2.1 Carbon sequestration. 2.2 Alternative Energy. 3 Legal mechanisms for carbon neutralization. 3.1 The polluter pays principle. 3.2 The Kyoto Protocol. 3.3 The Clean Development Mechanism. 3.4 The Paris Agreement. 3.5 The Conference of the Parties 23: COP Bonn. 4 The realization of carbon neutralization by means of development as freedom, Amartya Sen's theory. Conclusion. References.

\section{INTRODUCTION}

Global warming, due to the process of industrialization, population growth, urbanization and deforestation resulted in climate change, whose effects impact negatively, so that there is no control of the greenhouse effect, the scenario may become critical.

As a consequence, the way the nations might contribute to the implementation of carbon neutralizing measures capable of reducing the effects of global warming is discussed, since they are a result of a complex set of possible measures and actions, ranging from normative production and implementation, essential to the jurisdiction of the fundamental rights to an ecologically balanced environment and to an integral development.

In this study, the international mechanisms for carbon neutralization are analyzed, as a result of the greenhouse effect, with the aim to demonstrate the possibility of the rights effectuation through development as freedom, gathering the analysis regarding the process of dynamogenisis and education for the social, potentiating the means in favor of the fundamental right to integral development. The Amartya Sen's Theory presents itself as methodological nucleation, focusing on the development as freedom, increased by the wake of the subjects in this study.

Indeed, the major goal of this work is to show how the developmental theory as freedom, through a dynamogenic process, might ensure a balanced environment, assuring an integral development for future generations.

This study is justified because of the need to search for solutions to stop the negative consequences related to the increase of global warming and greenhouse effect, which demand urgent actions by the nations worldwide.

Therefore, considerations are brought about the consequences of the greenhouse effect and global warming, given the need for the implementation of the carbon neutralization, the legal mechanisms used worldwide for its scope, with emphasis on the Kyoto Protocol and its Clean Development Mechanisms and the Paris Agreement.

This investigation adopts the critical analytical methodology, relating the developmental theory to freedom, normative production, and education, which are essential for the participation of individuals in the construction of the values of society, in order to achieve an integral developmental purpose.

The literature review demonstrates the relevance of research directed to the effectiveness of the carbon neutralization, premise of the ecologically balanced environment and the right to integral development. The interpretation of the whole, vital core of the study indicates limits and possibilities in favor of the collimated purposes. 
Finally, it was found that the theory of development as freedom, which takes into account the education for purposes of political, economic and social development, giving the necessary freedom for individuals to participate in the formation of the society values, has relevant principles to make believe that their application can provide solutions to the achievement of the goals of reducing greenhouse gases, thus ensuring decent conditions of life for future generations, through a process of dynamogenesis that ensures the integral development, financially viable, socially fair and environmentally responsible.

\section{THE GREENHOUSE EFFECT AND GLOBAL WARMING}

The Planet Earth passed through climate changes that have resulted in global warming, whose result was the artificial increase in average temperature of the surface, due to the increase of the emission of gases, mainly of the industrialization process, which has as starting point the industrial revolution and endures with greater intensity until the current days, added to the population growth, urbanization and deforestation.

Global warming is a result of the greenhouse effect, which in its natural essence, without the externalities resulting from artificial increase of temperature, is essential to make it available the existence of life on the planet's surface, a time which consists of retaining the atmosphere of a part of the heat generated by solar radiation, produced by greenhouse gases (GHG), among which the water vapor $(\mathrm{H} 2 \mathrm{O})$, carbon dioxide $(\mathrm{CO} 2)$ and methane $(\mathrm{CH} 4)$ are highlighted (VIDAL, 2017, p. 4).

Danielle Limiro (2009, p. 23) refers to the greenhouse effect as "physical process by which the presence of atmospheric gases caused the earth to keep an equilibrium temperature greater than it would have if these gases were absent".

Celso Fiorillo (2005, p. 173), defines the greenhouse effect as:

The phenomenon of thermal insulation of the planet, due to the presence of certain gases in the atmosphere, i.e., it is the global warming of the Earth's surface temperature due to the large amount of toxic gases from the burning of fossil fuels (coal and oil, forests and pastures).

The term emissions refers to the retention of heat from the sun similar to retention caused by the glass in a greenhouse of plants. This phenomenon is responsible for the natural warming of the planet, being probably the most important for the maintenance of life on Earth, because without it the average temperature of the globe would be $-18^{\circ} \mathrm{C}$, against the current $15^{\circ} \mathrm{C}$ (VIDAL, 2017, p. 4).

However, the influence of man, mainly through the process of industrialization, has been causing an increase of the emission of these gases that compose the greenhouse effect, resulting in global warming exceeding the acceptable for the maintenance of the climate balance.

Among the sources that result in artificial increase of temperature through the greenhouse effect, Charles Armada and Daniela Binotto (2016, p. 92) emphasize that CO2 is a gas that has a greater contribution to global warming, because it represents more than $70 \%$ of GHG emissions and its time of permanence is at least 100 years, resulting in impacts on climate over the centuries. It adds up, still, that methane, despite its comparatively low concentration (in relation to the $\mathrm{CO} 2$ ) and its useful life in the atmosphere be low (approximately 12 years), has a significant impact on climate change. Over a period of 100 years, it has 25 times the global warming potential of CO2; however, in the short term, this is much stronger: has a global warming potential 72 times higher than the $\mathrm{CO} 2$ along a temporal average of 20 years. In the case of $\mathrm{N} 2 \mathrm{O}$ and chlorofluorocarbons (CFCs), their concentrations in the atmosphere are smaller, but their power to retain heat is from 310 to 7,100 times greater than the $\mathrm{CO} 2$. 
Thus, in the last two centuries, the increase of the petroleum, natural gas and coal burning, as well as the increase of soil use on a large scale in function of agriculture and also of deforestation, resulted in a significant increase in the emission of one of the gases responsible for the greenhouse effect: the carbon dioxide - $\mathrm{CO} 2$.

This increase in the globe temperature can cause drastic climate change, able to threaten the quality of life, the socioeconomic pattern and even the existence of man, among which stands out: the increase in the level of the oceans; the emergence and growth of deserts; the imbalance in ecosystems, which will result in new pests and diseases; the increase of hurricanes, typhoons and cyclones; heat waves; and the melting of permafrost, the permanently frozen soils of the Arctic region (VIDAL, 2017, p. 5-6).

\section{CARBON NEUTRALIZATION: FUNDAMENTAL RIGHT TO DEVELOPMENT}

The Brazilian Institute of Defense of Nature - IBDN points out that the carbon neutralization consists of reducing the impacts to the environment, conducted by emissions of greenhouse effect gases - GEE. In the case of carbon dioxide, this neutralization is carried out by means of a compensation of its emission, which occurs due to the dimensioning of the impacts resulting from it, seeking an amortization through positive behaviors that result in the reduction of this gas in the atmosphere, i.e., the objective is to remove from the atmosphere the same amount of carbon dioxide added by human activities, thus maintaining the natural balance of the greenhouse effect (BRAZIL. The Brazilian Institute of Defense of Nature - IBDN, 2017).

Regarding this, Jonathan Ramseur (2008, p. 9-10) clarifies that the carbon neutralization has as main goal to reduce, avoid or sequester emissions of this gas in the atmosphere, pointing that the compensation can occur through projects, among which stands out: the sequestration of carbon, renewable energy and energy efficiency.

The carbon sequestration occurs by means of trees, plants and soils, which hold the carbon, removing it from the earth's atmosphere. The projects involve activities that increase the potential for carbon fixation or retain existing ones, such as the planting of new trees, for example.

The renewable or alternative energy, consists of projects related to energy production that involve the wind, solar energy and biomass, known as renewable energies. These energies generate fewer emissions of carbon dioxide than fossil fuels, which are the main sources of emission. Thus, projects such as the construction of wind turbines to generate electricity, addition of solar panels, adaptation of boilers to accommodate the biomass fuels are examples of use of renewable energies.

In the same way, the efficiency aims to achieve more efficient products in terms of energy consumption, such as updating of machinery or equipment, making them more efficient; replacement of incandescent light bulbs with fluorescent bulbs, etc.

In this context, it is verified that the carbon neutralization is a solution able to solve the problems caused by the greenhouse effect and global warming, for which reason it should be treated as a fundamental right to development, this in its full meaning, i.e., financially viable, socially just and environmentally responsible (SILVEIRA, 2017, p. 54).

It is worth stressing that the right to development at the national level is taken expressly for fundamental, since the Federal Constitution makes reference to it in its preamble and Article 3, II, there is still simple reference in article 5, XXIX (CAMPELLO; ANDRADE; SANTIAGO, 2018, p. $10)$.

Thus, the theme can be treated as a process of dynamogenesis, as it refers to the discovery of values by society and social accession to them, whose implementation will be through the law in its standardization production and the realization can be captained by education.

According to Silveira and Rocasolano (2010, p. 191), the dynamogenesis 
refers to the continuing process in which the values are immersed, and which can be summed up in the following steps: 1) knowledge-discovery of values by society; 2) eventual accession to social values and the immediate consequence; and 3) Implementation of the values through the law in its normative and institutional production.

Adding to the education arising from development as freedom and the protection of the environment in this process of dynamogenesis, favorable conditions are gathered for the effectiveness of the fundamental right to development, taking by consequent reflection, the relevant question of carbon neutralization.

\subsection{Carbon sequestration}

The carbon sequestration, also called biological sequestration, has legal provision in article 2, Section IV, of the Kyoto Protocol ${ }^{1}$, whose purpose is to contain and reverse the accumulation of $\mathrm{CO} 2$ in the atmosphere, aiming at the reduction of greenhouse gases.

It is a process of removing carbon dioxide gas that occurs mainly in oceans, forests and other bodies which, through photosynthesis, capture carbon and release oxygen into the atmosphere. It is the capture and secure storage of carbon dioxide (CO2), thus preventing its emission and permanence in the earth's atmosphere.

Marcilene Pereira (2009, p. 38-39) defines the sequestration of carbon "as capture and secure storage of $\mathrm{CO}$, which otherwise would be emitted to the atmosphere or would remain in it". The whole process (capture, transport and storage) is known by the acronym CCS, abbreviation of the English - CO2 Capture and Storage, capture and storage of CO2. Still, the author highlights the existence of two mechanisms: direct and indirect sequestration.

In the indirect sequestration, also known as biological, atmospheric $\mathrm{CO} 2$ is captured and fixed, stimulating the ability of terrestrial and marine ecosystems to absorb it naturally and store it in biomass, for example, by means of reforestation activities and fertilization of the oceans.

The direct sequestration involves capturing the $\mathrm{CO} 2$ from the burning of fossil fuels, before it reaches the atmosphere. It has a higher cost and also greater efficiency. For example: the $\mathrm{CO} 2$ can be separated from the gaseous effluents generated in thermoelectric plants, in industrial processes, such as petroleum refineries and steel mills, or during the production of decarbonized fuels.

\subsection{Alternative Energy}

The Intergovernmental Panel on Climate Change - IPCC (2017, p. 7-10), clarifies that the alternative energies are those capable of supplying electricity and mechanical energy and produce fuels with the purpose to satisfy the multiple needs of dependent services of energy, replacing the burning of fossil fuels and coal. Among them stands the biomass, biothermal energy, hydropower, ocean energy, solar energy and wind energy.

The bioenergy is derived from the conversion of biomass into fuel. Biomass is any organic matter, derived from plants or animals, available on a renewable basis. It can be derived from wood scraps, agricultural waste, organic municipal waste, of dung etc. energy from biomass corresponds

\footnotetext{
1. Article 2. 1 - Each Party included in Annex I, upon complying with their quantified emission limitation and reduction of emissions assumed under Article 3, in order to promote sustainable development, shall:(a) implement and/or improve policies and measures in accordance with its national circumstances, such as:

$\cdots$

IV. The research, promotion, development and increased use of new and renewable forms of energy, technologies for carbon dioxide sequestration and environmentally safe technologies, which are advanced and innovative.
} 
to biofuels ethanol, biodiesel, biogas.

Geothermal energy is obtained from the heat from the earth's interior. This energy can be used directly (without the production of energy in power plants, using only the heat generated by the soil) or indirectly (when the heat is routed to an industry that transforms it into electrical energy).

The hydroelectric is obtained from the force of the fall of the waters. Brazil is the second country in the world with the greatest capacity and generation of hydropower, only behind China. The hydroelectric plants use an elevation to increase the strength of the water and rotate the turbines to produce electrical energy.

The oceans energy comes mainly from tides (tidal energy) or waves (wave energy). The energy source is still little used, therefore, to be efficient and economically viable, the coast needs to have specific characteristics, such as tides larger than three meters. The cost is high, which makes this type of energy not attractive, when compared to other sources.

The energy from the sun is the most promising for the future, and that receives more investments. The solar radiation can be captured by photovoltaic plates and be converted into thermal energy or electricity. When panels are located in buildings, such as houses or industries, the environmental impacts are minimal. This type of energy is one of the easiest to be deployed in the own establishments that want to reduce their $\mathrm{CO} 2$ emissions.

In terms of wind power, it is noteworthy that the emission of carbon dioxide, which comes from it, is lower than the solar energy. Investments in wind parks are a great option for the carbon neutralization emitted by companies, activities, processes, events, etc.

These last two sources of energy are generated with greater simplicity, what causes, besides the reduction of emission of gases, also a consequent reduction in costs when accounting for all the required processes. This is because, if compared to fossil fuels and coal burning, these sources of energy do not need to be extracted, refined and transported to the generation site. They do not exhibit costs with transmission in high voltage. The need for maintenance is minimal, resulting in economic benefits.

In relation to the generation of solar energy, the most promising, the following is also emphasized: the reduction of losses in transmission and distribution of energy, since the electricity is consumed where it is produced; the reduction of investments in transmission and distribution lines; the non-requirement of dedicated physical area, and the rapid installation due to its great modularity and short deadlines for installation, which enables the generation of electrical energy at any point or edification.

In this context, considering the medium and long term, referred to renewable energy will only bring benefits and advantages, having in view the capacity of neutralization of the emission of gaseous pollutants, as well as their greater economic viability, considering the investments of installation, the costs of energy production and maintenance of the system are small financial expression.

\section{LEGAL MECHANISMS FOR CARBON NEUTRALIZATION}

The climate changes that caused the artificial increase in average temperature of the Earth's surface, coming mainly from the process of industrialization, increasing the emissions of greenhouse gases, resulted in the heating above the acceptable for the maintenance of the climate balance.

According to Danielle Limiro (2009, p. 20), "we have been facing a global warming never experienced by our planet and fully differentiated in a pre-Glacial Era", which has led to important discussions on the international scene.

In this context, some international conventions on climate have been carried out over the years, in view of the need to develop legal mechanisms that bound the countries, major emitters of 
greenhouse gases. Everything in the light of growing concern with global warming, standing out among these mechanisms: the affirmations of the principle of polluter pays principle; the Kyoto Protocol, which provides for, among other measures, mechanisms for carbon neutralization and clean development mechanism, and the current Agreement of Paris.

\subsection{The polluter pays principle}

The polluter pays principle is corroborated by the redistributive denomination of Environmental Law, having in view that provides the internalization by part of the productive agent of external costs that fall on society (MILARÉ, 2005, p. 163).

Thus, this principle has as premise that the polluter should assume the responsibility with the costs of prevention, mitigation and repair of the damaged good.

Messias and Souza (2015, p. 95) explain that this is a principle that aims to impose the polluter the payment of the costs relating to the prevention and/or repair of environmental damage that its venture may cause or have caused.

The interpretation directed to the polluter's interests was distorted, not being able to accept directions in favor of the understanding of an inverted logic to allow the reasoning that it was possible to pollute, provided that they paid.

Cristiane Derani (1997, p. 157) states that:

The objectification of this principle by the law happens when it establishes standards of what can and what cannot be done, as well as flexible rules, dealing with compensation, offering, including, fees to be paid for the use of a natural resource.

The major objective of the polluter pays principle is to allow the agents that originated the externalities to assume the costs imposed on other agents, producers and/or consumers.

In the international context, this principle was made positive through the OECD Organization for Cooperation and Economic Development, through the recommendation C (72) $128,1972^{2}$.

Later, in the year of 1992, in the Rio Declaration on Environment and Development, the United Nations Conference adopted said thought of the polluter-pays principle by means of its Article 16, which required to appear in the following way:

The competent authorities shall seek to ensure the internalization of environmental costs and the use of economic instruments, taking into account the criterion of who pollutes, should, in principle, bear the costs of the contamination, considering the public interest and without distorting international trade and investment (UN, 1992).

Its affirmation in Brazil occurred primarily by means of Ordinary Law No. 6.938/81, which brought in its article 4, Section VII, as one of the purposes of the National Policy of Environment, the imposition of the obligation on the polluter and the predator "to recover and/or indemnify the damage caused and the user of the contribution by the use of environmental resources with economic purposes".

\footnotetext{
2. The Recommendation C (72) 128, OECD, deals with the economic aspects of environmental policies, clarifying that the principle that uses to affect the cost of measures for the prevention and control of pollution, to encourage the rational use of scarce environmental resources and to avoid distortions to trade and international investment, is called the polluter pays principle. This principle means that the polluter should bear the costs of the development of the aforementioned measures decided by public authorities to ensure that the environment is in an acceptable state.
} 
It was also approved by the Federal Constitution of 1988 in its art. 225, paragraph 3, which prescribes: "The harmful activities and behaviors affecting the environment will surrender the offenders, individuals or legal entities, the penal and administrative sanctions, regardless of the obligation to repair the damage caused."

Messias and Souza (2015, p. 95) emphasize that this principle is not authorizing pollution, but it is preventive and/or repressive, and should be interpreted combined to the constitutional principles of the dignity of the human person and of solidarity.

Thus, when it comes to the principle that the polluter imposes an obligation to recover and/or indemnify the damage caused, it is possible to consider it a legal mechanism of carbon neutralization.

\subsection{The Kyoto Protocol}

The Kyoto Protocol was signed in 1997 by representatives from more than 160 countries present at the Third United Nations Conference on Climate Change, resulting in complement to the United Nations Conference on Environment and Development - ECO 92, held in Rio de Janeiro.

The aforementioned international treaty entered into force in 2005, after the realization of the required minimum number of adhesions, which was supplied by Russia's membership in the previous year. Currently, 184 countries have signed and ratified the protocol (BRAZIL, 2010).

The main objective was to stabilize the emission of greenhouse gases (GHG) into the atmosphere, and thus break the global warming and its possible impacts, referred to in item 1 of article 3:

The Parties included in Annex I shall, individually or jointly, ensure that their aggregate anthropogenic emissions, expressed in carbon dioxide equivalent of greenhouse gases listed in Annex A do not exceed their assigned amounts, calculated in accordance with their quantified emission limitation and reduction commitments of emissions described in Annex B and in accordance with the provisions of this Article, with a view to reducing their total emissions of these gases by at least 5 percent below 1990 levels in the commitment period from 2008 to 2012 (BRAZIL, 2002).

The signatory countries were divided into two groups, according to their level of industrialization, which bestowed upon them distinct obligations outside the Protocol. Annex I gather the developed countries, while the other signatory countries make up the group of developing countries, among which is the United States.

Therefore, this agreement imposes a great task to the nations, establishing common responsibilities; however, differentiated. This is because the countries that compose the Annex I committed to reduce their greenhouse gas emissions by an average of five percent in relation to the levels that emitted in 1990, with a deadline for completion of the goal in the year of 2012, while the countries not listed in that Annex shall only assist in the reduction of emission of these gases and put into practice projects for Clean Development Mechanism (CDM); however, without mandatory targets.

Thus, in view of the fact that the accomplishment of goals would entail large economic efforts of the parties, the protocol established three flexibilization mechanisms: (i) Joint Implementation; (ii) Trade in emissions; and (iii) The Clean Development Mechanism (CDM).

Joint Implementation has support in Articles 3 and 4 of the protocol, allowing two or more Annex I countries to implement jointly projects that reduce GHG emissions.

Emissions trading is laid down in its article 17, which establishes:

The Conference of the Parties shall define the appropriate principles, modalities, 
rules and guidelines, in particular for verification, reporting and accountability for emissions trading. The Parties included in Annex B may participate in emissions trading, with the objective of fulfilling their commitments under Article 3. Such trading shall be supplemental to domestic actions with a view to meet the quantified emission limitation and reduction of emissions commitments under this Article (BRAZIL, 2002).

It is verified that, through the mechanism of Emissions Trading, when a country of Annex I has already reduced the emission of GHG emissions in addition to its goal, it is possible to sell the surplus to another country of the same annex which has not reached the goal.

Among the mechanisms for flexibility, the Clean Development Mechanism is the only one that allows the participation of developing countries, not listed in Annex I, whose prediction is based on Article 12 of the protocol, as better demonstrated below.

\subsection{The Clean Development Mechanism}

The Clean Development Mechanism (CDM - refers to one of the mechanisms for Flexibilization brought by the Kyoto Protocol to enable compliance with the goal of reducing the emission of gases, whose prediction is based on Article 12 of the instrument, which reads:

Article 12

1. It is set a clean development mechanism.

2. The purpose of the clean development mechanism shall be to assist Parties not included in Annex I in order to achieve sustainable development and contribute to the ultimate objective of the Convention, and to assist the parties included in Annex I to comply with their quantified emission limitation and emissions reduction, assumed under Article 3.

3. Under the clean development mechanism: (a) Parties not included in Annex I will benefit from project activities resulting in certified emission reductions; and (b) The Parties included in Annex I may use the certified emission reductions resulting from such project activities to contribute to compliance with part of their quantified emission limitation and emission reduction assumed under Article 3, as determined by the Conference of the Parties serving as the meeting of the Parties to this Protocol (BRAZIL, 2002).

According to Dainezi (2011, p. 60-73), this mechanism allows Annex I countries to achieve their goals, buy certified reductions arising from reductions carried out in developing countries.

It is observed that the purpose of the CDM is to serve as a tool to assist the parties that make up the Annex I in the reduction of emissions of greenhouse gases, allowing them the fulfillment of the commitments signed in the agreement. This mechanism is the only one that provides for the participation of developing countries not listed in Annex I, such as Brazil, in a way that allows for funding of projects for reduction of emissions by developed countries (Annex I) to be carried out in developing countries (Annex I).

Reinaldo Dias (2008, p. 124) adds that:

This mechanism represents a form of cooperation through joint implementation and emissions trading, allowing developed countries meet their goals through funding of projects in developing countries, such as: conservation of protected natural areas, reforestation, efficient lighting in industrial processes, etc.

CDM has a large importance, to the extent that enables the transfer of clean technologies and sustainable development by governments and large private companies of Annex I countries to 
developing countries, bearing in mind that they have great interest in the financing of projects that result in carbon credits, which will provide the goal of reducing GHG emissions, as well as the possibility to continue exercising industrial activity in the search for greater development and respective financial result.

The credits resulting from CDM projects are obtained in the form of securities denominated in Certified Emission Reductions - CERS, which provides the purchasing of these credits by developed countries in developing countries, assisting in compliance with the reduction target.

The interest in the purchase of CERS is mainly in the fact that the costs of reducing emissions in Annex I countries are extremely superior in relation to these costs in developing countries. In the case of Brazil, for example, due to the abundance of natural resources, such as the vast watershed, the vast plains and plateaus, the costs for the production of clean energy can be much smaller.

The development of CDM projects, therefore, is a great development opportunity for countries which are not listed in Annex I, since they allow the entry of foreign countries, mainly generating new jobs, environmental quality improvements and modernization of productive activities. This set of aggregate factors will result in competitive in the long term (CASARA, 2009, p. 94).

However, while some countries defended this position that this mechanism should operate as a carbon market, with the purchase and sale of credits, others believed that the most appropriate way would be the creation of an international fund.

The increasing participation of individuals in the construction of mechanisms of global environmental governance, which are not part, necessarily, nor of the scientific community and civil society organizations, called "ad hoc" negotiators, was of great importance for the implementation of the Kyoto Protocol and the Clean Development Mechanisms, as well as for the success in the climate negotiations in the general context, especially highlighting Al Gore, Bill Gates, Tony Blair, Kofi Annan, among others, worth mentioning also in the regional scenario Fernando Henrique Cardoso and Fábio Feldman (VENTURA, 2008, p. 40).

Upon the implementation of the CDM, many cons and pros arguments to climate cooperation were referenced as punctuated by Dutschke (2000, p. 11).

As arguments to the contrary, it is mentioned in synthesis: the responsibility of developed countries, the sovereignty, the ruinous competition and the bargaining power of the developed countries, future costs, since the achievement of more inexpensive options for reducing emissions today will affect the least developed countries in the future, and when they want to adopt their own limits, have higher marginal costs for each reduced ton (DUTSCHKE, 2000, p. 11).

In contrast, it presents in summary, favorable arguments such as: cost efficiency, the leapfrogging, global commons, globalization, the reduction of gases as a new product, temporal advantage, non-renewable resources, future obligations and emission limits for the developing countries, even if the future they accede to Annex I, they shall be negotiated according to their potential and reductions already made (DUTSCHKE, 2000, p. 11-12).

Between opposing and favorable positions, the reality is that the deployment of the MDLS made it possible also the creation of various voluntary marketing initiatives of RECS on the part of developed countries, currently traded on stock exchanges around the world.

It was in this scenario, considering the criticism and the benefits that the Clean Development Mechanisms, with regulated procedures and laid down in the Kyoto Protocol, appeared to the world.

In order to be eligible under the CDM, and start to have validity and recognition in the quality of CERS, the project activities must contribute to the primary objective of the UN Framework Convention on Climate Change and observe some fundamental criteria, prescribed in item 5 of article 12 of the Kyoto Protocol, among which: (a) voluntary participation; (b) approval 
of the country of origin; (c) care for sustainable development objectives; (d) reduction of emissions additionally to what would occur in the absence of the CDM project activity; (e) the accounting of emissions that occurs outside the limits of the project; (f) consultation of all the actors who will suffer the impacts of the project activities (stakeholders); (g) a guarantee not to cause negative collateral impacts to the local environment; (h) production of measurable benefits, real and longterm related to the mitigation of climate change; and (i) relationship with the gases and sectors as defined in Annex A of the Kyoto Protocol or with activities of projects for reforestation and afforestation (BRAZIL, 2002).

Regarding these requirements, an important consideration is brought by Danielle Limiro (2009, p. 83), stating that:

It is not enough simply to reach a level of emission reductions for a brief period to alleviate climate change, it is necessary that this period be extended to the vertiginous growth of global warming and, consequently, the possibility of disasters be prevented.

In the sequence, so that they result in CERS, the activities of CDM project must pass through the stages of the project cycle, namely: (a) Preparation of the Project Design Document (DCP or, in English, PDD, Project Design Document); (b) Validation by the Designated Operational Entity (EOD); (c) Approval by the Designated National Authority (DNA); (d) record in the CDM Executive Board; (e) monitoring; (f) verification and certification by the Designated Operational Entity; and (g) Issuance of CERS by the CDM Executive Board (FELIPETTO, 2007, p. 15-16).

The Kyoto Protocol establishes, still, that both private companies and the public can participate in projects for Clean Development Mechanism, with a view to the acquisition of CERS.

According to information available at the electronic address of the United Nations Framework Convention on Climate Change, until October 02nd 2018, there were 8,157 registered CDM projects in the body in the world, counting t Brazil with 384 registrations (UNFCCC, 2017).

The first project of clean development mechanism registered in the world is the Novagerar, whose purpose is to produce energy from garbage methane gas, in Nova Iguacu (RJ). Currently, it reduces the emission of methane, breaking this gas into $\mathrm{CO} 2$, which is much less polluting (ARAÚJO, 2006, p. 33).

At national level, the Law 12.187/09 instituted the National Policy on Climate Change (PNMC), whereas the CDM is an instrument which aims at the consolidation of a low-carbon economy. In the sectoral plans for mitigation and adaptation to climate change, CDM involves the creation of small hydropower, wind parks and digesters.

It is worth noting that, in Brazil, the development of CDM projects also occurs through collaboration between the public and private sectors, through alliances among the first, second and third sectors, which occur by covenants, management contracts and terms of partnership. This collaboration has resulted, for example, in the approval of project to "capture and combustion of methane gas $(\mathrm{CH} 4)$ through the system of management of swine's production of integrated farms of Participants in the Program 3S of Sadia Institute" (APP, 2017).

\subsection{The Paris Agreement}

Currently, the targets for the reduction of GHG emissions are drawn by the Paris Agreement, which was regulated by the Conference of the Parties on Climate Change (COP22), at the end of the year 2016.

The Paris Agreement was entered into by 195 countries, with the same objective: to prevent global warming by reducing the emission of greenhouse gases. Thus, it was established that the increase in global temperature should be below 2 degrees Celsius above pre-industrial 
levels, with the commitment that all countries reach the peak of their emissions as soon as possible, aiming at, in the second half of this century, the EGE that artificially inflate the greenhouse effect and fossil fuels are abandoned in almost their entirety.

Unlike the Kyoto Protocol, the Paris Agreement stipulates that each country must submit, every five years, national plans with the goals of reducing GHG emissions. In this perspective, including the developing countries should take reduction targets, within their possibilities, in order to improve efforts to combat global warming. Such agreement, approved in 2015, entered into force in 2016, 30 days after its ratification by 55 countries. It was regulated by means of COP 22, which occurred in 2016, opportunity in which more than 190 signatory countries of the Paris Agreement reaffirmed the commitment to reduce global warming and build a work agenda, aimed at this purpose. The rulers have defined the year 2018 as the deadline for the beginning of the operationalization of the Agreement, announcing important initiatives, particularly regarding the Marrakesh Vision, which consists of the ambitious commitment of the countries to implement the use of $100 \%$ renewable energy between 2030 and 2050.

By means of COP 22, each country presented voluntary targets for the development within their territories. Brazil presented an ambitious goal: reduction of $37 \%$ of the GHG emissions by the year 2025 (Brazil, 2016).

In June 2017, Donald Trump, President of the United States, facing all the international community, has announced the departure of its country from the Agreement. He explained that, in order to fulfill his duty to protect America, the United States will withdraw from the Paris Climate Agreement and begin renegotiations to reenter the agreement in a way that is fair with the American people.

In only 100 days of government, Trump undid 23 environmental regulations established by the government of Barak Obama. According to issue conveyed by The New York Times, in May 2017:

President Trump, with the help of his administration and Republicans in Congress, reversed course in almost two dozen environmental rules, regulations and other policies of the era of Obama during his first 100 days in the position. Citing the Federal overreach and burdensome regulations, Mr. Trump has prioritized the domestic interests of fossil fuels at the expense of measures to protect the environment and to limit the global warming ${ }^{3}$ (POPOVICH; SCHLOSSBERG, 2017, our translation).

The justification for such measures is to rewrite the plan of Clean Energy in the United States, one of the most important environmental measures of the Obama administration, as well as increase the facilities of oil extraction and coal, which will result in an increase in jobs for the American Coal Industry (CALIXTO, 2017, n.p).

However, in addition to causing negative impacts to the achievement of the objectives of the Paris Agreement, the line followed by Trump does not seem to be the most sensible. This is because the rescue in large scale use of fossil fuels and coal does not necessarily mean an increase of jobs, which can also be generated through the development of mechanisms for clean energy. It is added to the efficiency gain in the long term, considering that the clean energies, as already demonstrated, have lower maintenance cost.

Moreover, this is not the only point that needs to be addressed. The lack of collaboration to reduce the heating of the planet would entail environmental problems, about which the Trump

\footnotetext{
3. In the original: "President Trump, with help from his administration and Republicans in Congress, has reversed course on nearly two dozen environmental rules, regulations and other Obama-era policies during his first 100 days in office. Citing federal overreach and burdensome regulations, Mr. Trump has prioritized domestic fossil fuel interests and undone measures aimed at protecting the environment and limiting global warming"
} 
cannot simply announce a wall on the border to prevent their impacts.

The United States is already facing the effects of an unregulated climate, as waves of heat and change in patterns of storms. Recently, in September 2017, the hurricane Irma hit Florida on quality of the strongest hurricane ever recorded in the Atlantic basin, causing catastrophic damage, leaving dozens of deaths in the Caribbean and more than fifty only in Florida.

The problem of the Trump's posture is that reversing the effects of global warming is not as fast as his rash attitudes against the government of his country, before which the population has suffered the greatest losses, considering that the outcome of major hurricanes, as Irma, is precisely the global warming in the Arctic. Added to this, there is still that, upon abandoning the leadership that the United States built in climate negotiations, if no other nation takes over this process, the world climate may become even more misruled.

\subsection{The Conference of the Parties 23: COP Bonn}

COP22, held in Marrakech in the year 2016, represented the first conference that served as the meeting of the parties to the Paris Agreement, providing a platform for the nations to unite, with the aim of building a low-carbon future.

However, with the recent leaving of the United States from the Agreement, COP 23 generated special expectation, in view of the uncertainties that remained with the absence of the holder of the strongest economy and most polluting the world and, until then, leader of the global movement for the carbon reduction.

COP 23 occurred in November 2017, in Bonn, Germany, organized by the Government of Fiji, a small island state of the Pacific (COP-22, 2017). Fiji is an integral part of the Alliance of Small Island States (AOSIS), a coalition of small islands and low coastal countries that share challenges and concerns of similar development on the environment, especially its vulnerability to adverse effects of global climate change.

AOSIS has a special interest in conferences of the Parties, pointing that the COP 23 occurred as a result of one of the worst seasons of hurricanes already registered, which devastated several members of the Alliance, including Antigua and Barbuda, Dominica and Cuba, resulting in several deaths and causing damage of at least $\$ 40$ billion (AOSIS. ORG, 2017).

President of AOSIS, Thoriq Ibrahim, Minister for Energy and Environment of the Maldives, stated that "the hurricanes Irma and Maria brought the real impact of climate change on small islands clearly". It was added that "if the scenes of total devastation in the Caribbean is not sufficient evidence of the reality of loss and damage, I do not know what it is like." However, it brought an important counterpoint, stating that "fortunately, we saw a coup in support for the Paris Agreement, because the main economies announced very ambitious initiatives. We hope that this momentum will continue" (AOSIS.ORG, 2017).

In this context, COP 23 was an important milestone to deconstruct the idea that the United States' leaving of the Paris Agreement would cause a domino effect, because, on the contrary, resulted in a kind of determination among other countries, which are even more aware that we need global cooperation to be conducted with seriousness, with or without the richest and most polluting nation of the planet.

In addition, universities, mayors, business leaders, and governors throughout the USA launched a campaign called "WeAreStillIn", representing more than 127 million Americans and 6.2 trillion dollars in economic power. In a robust demonstration of support for climate negotiations, the coalition has a clear message that remain s committed and that the action of the country on climate issues will not be limited by policies in the federal sphere (BARBOSA, 2017, n.p).

In December 2018, COP 24 will take place in Katowice, Poland, in which will be 
strengthened the efforts of Fiji to accelerate progress in finalizing the "Rules Book"4document that will guide the implementation of the Paris Agreement and ensure extended and predictable financing for developing countries.

Thus, the Conference of the Parties, in 2017, it became the goals of the Paris Agreement more alive than ever, for the purpose of constructing the transverse partnerships necessary to catalyze the exchange of global knowledge and provide a springboard for the world leaders' actions.

\section{THE EFFECTIVATION OF THE CARBON NEUTRALIZATION: SEN AMARTYA'S THEORY ON DEVELOPMENT AS FREEDOM}

The Nations, considering the respective forms of organization, depend on the society as means and form to achieve goals and governmental agreements, involving the commitment of its citizens, who will be the coparticipants of the achievement of goals, targets and agreements at national or international level.

José Francisco Rezek (1996, p. 160) puts people as an essential element in the State formation, affirming that "the State boasts three combined elements: a territorial basis, a human community established on this area and a form of non-subordinate government to any external authority".

In this context, Hobbes (2000, p. 145) punctuates the importance of mutual pacts of the population to achieve the goals of the State, working on the idea that "to the crowd hence united in one person is called the State [...] This is the generation of that great Leviathan [...] to which we owe our peace and defense $[\ldots]$ ".

In addition, the current moment is characterized by a number of movements - personal and state - that do not only understand the difference of others - ethnic, cultural, religious, and they abhor and condemn, in hasty trials (CALETTI; STAFFEN, 2017, p. 111).

In this context, in order to achieve the objectives outlined in the international context by the nations, not just the mere signing of their representatives, however, before a sense of responsibility is achieved, and, fundamentally, the commitment of its citizens, essential components of all the so-called State. It is in this context that the development as freedom, diffused by Amartya Sen, means essential to the citizens' emancipation, enabling him or her to facilitate joint actions of solidarity as the carbon neutralization, apprehending the relevance and need to contribute to the planet preservation and the conditions of the global society. The line of reasoning outlined by Sen contextualizes the development seen as a process of expansion of substantive freedoms of people, which is inherently multifaceted, involving considerations about processes and substantive opportunities.

Amartya Sen (2010, p. 53-55) point that there are two types of freedoms: (i) substantive (freedom as the end of the development), represented by the basic capabilities, such as being able to avoid hardship as hunger, malnutrition and premature death, apart from those corresponding to learn to read, have political participation and freedom of expression; and (ii) the instrumental freedoms (freedom as a means of development), which represent how different types of rights, opportunities and guarantees contribute to the expansion of human freedom in general and, thus, for the promotion of development. Among these he lists the following ones: the political freedoms, economic, social opportunities, the guarantees of transparency and the protective security as species of instrumental freedoms.

He states that:

4. Document that will present criteria for measuring the reduction of carbon dioxide emissions and supervision of these goals. 
The future can be molded by us. This could be done by basing our choices on reason. We need, then, an appropriate evaluation structure; we also need institutions that act to promote our goals and commitments, commodity and, in addition, standards of behavior and a reasoning about the behavior that will allow us to realize that we have been trying to accomplish (SEN, 2010, p. 318).

This is because the social structure existing in the majority of countries, in their great majority does not allow the individuals the reasoning about the behavior, due to the lack of an appropriate evaluation structure, which occurs due to the lack of substantive freedoms, due to the fact that a large proportion of the world's population still lives below the poverty line, and without the minimum conditions of hygiene and sanitation.

Thus, he presents the great importance of the values and the reasoning for the increase of freedoms and for the achievement of development, highlighting the importance of the discussion and public interactions in the emergence of common values and commitments, considering that the ideas about what is right and what is not can be influenced by the arguments presented for public discussion (SEN, 2010, p. 323).

However, only with the granting of substantive freedoms, individuals will be able to participate in discussions and public interactions by exerting some rationality, since, without having the minimum existential to survive, the purpose of life is only the minimum scope of this situation of survival with the minimum of dignity.

The effectiveness of public policies should not be restricted to the State action and to the social provision, it should be scope for the development of social values and a sense of responsibility that will reduce the impositive action of the State (SEN, 2010, p. 343). The conception of self-interest must contain in itself the concern for others, so that the power of reason allows to take into account the obligations and ideals in the social context.

Thus, the public policies may not be employed only as a social patch, and must provide in its fullness the substantive freedoms, which, once established, will allow the scope of instrumental freedoms. Otherwise, not giving at least the substantive freedoms, public policies, instead of setting someone free, will salve the social layer more devoid of resources of all kinds, including education, health, employment, security, basic sanitation and the reduction of the environmental impact.

Added to this, so that public policies be viable and accepted by individuals, it is imperative that they be in tune with the values of the public in general, including their sense of justice.

In the wake of this understanding, Sen (2010, p. 361) clarifies that "responsibility requires freedom". However, having actually the freedom and the ability to do something requires the person the duty to reflect about doing it or not, and this involves individual responsibility. Thus, the freedom to participate in the critical evaluation and the process of values formation is, indeed, one of the most crucial freedoms of social existence.

Nonetheless, without the substantive freedoms, individuals will certainly not be able to reflect on what to do or not to do, what can be said as a rule in developing countries, preventing the sense of individual responsibility and, therefore, the participation in the process of values formation, providing the current situation in which the values are formed by the minority who appropriate themselves of the instrumental freedoms.

From the foregoing, for the support of her theory, he highlights the benefits of education for the viability of the whole freedom process, that exceeds the role of composing the human capital for mere production of goods, taking into consideration that the human capacity developed through education must also take into account the social and political developments, in the face of what people may, in fact, exercise the freedom in the formation of values of society, that will result in public policies of Member States, which makes the development as a process of expansion of the people's substantive freedoms (SEN, 2010, p. 373). 
The expansion of technical courses in developing countries, especially in Brazil, demonstrates that it is lived the opposite of this juncture, now that the qualification of human capital will turn to the mere production of goods, without any concern with the social and political development, context that needs to be revised to the viability of the reach of instrumental freedoms, enabling the values formation able to reflect the true interests of the society.

Thus, the reasoning developed by Amartya Sen has grounds to make believe that its application can provide solutions to the achievement of the goals of protecting the environment with a reduction of greenhouse gases as a means of achieving the right to development.

The Kyoto Protocol, multilateral legal mechanism created for the reduction of emission of these gases, was not able to achieve the results that are necessary to prevent the increase of global warming. This Protocol did not bring obligations for all the countries (only for those of Annex I), as well as does not provide means of coercion for those who did not fulfill their part of the agreement.

Currently, as already contextualized, giving continuity to the interests that sustained the Kyoto Protocol the Paris Agreement was approved that, differently, determines that each country must submit, every five years, national plans with the goals of reducing GHG emissions, so that, by assigning a greater degree of freedom in relation to the participation of countries, regarding the policy to be developed, grants them greater responsibility. Such positioning reflects Amartya Sen's theory, which according to him having effectively freedom and the ability to do something requires the person the duty to reflect about doing it or not, and this involves individual responsibility.

In this sense, there is a situation in which the objectives of the Agreement were traced through the participation of each member, exposing their individual interests, arising out of the values of each one, which culminated in the understanding of the responsibilities in the light of freedom to which they have been given.

However, this freedom must understand a collective responsibility, involving the responsibility of the State and society; but with the consciousness of the individuals of their individual responsibilities, without revealing the idea that all should be responsible for all, under penalty of generating the opposite effect, because it can transmit the feeling that nobody needs to take responsibility, having in view there is always have someone to be blamed in their place, which is why it is essential the participation of all in the construction of the society values.

The solution to the problem does not cover only the signature of the Agreement on the part of the States leaders, but especially the participation of the population of each one of them, fomented appropriately and participatorily.

Thus, Barba Homem (2003, p. 314) on the formation and reason of State, says that in order to understand the modern State, in addition to issues such as war and peace related and dependent on international diplomacy, requires the study of the law of nations, as well as the understanding of the formation and reason of State.

Observing this juncture, added to the teachings of Amartya Sen, we have that the public policies of each Member State must be in harmony with the values of its citizens, making their responsibilities originate from the freedom given to each one. However, so that people be able to exercise their freedom, taking into account the political and social developments, it is necessary to be gifted with the benefit of education, which provide them with a real condition of freedom, both substantive and instrumental.

It is worth stressing that sustainable development presupposes that humanity will dramatically change their current course to ensure a safe and healthy life for future generations, whose focus is on a balanced combination of environmental, economic and social development, i.e., the full sustainability (CAMPELLO; SILVEIRA, 2016, p. 570).

In this context, through the individual and for the social education, granting the freedom to participate in the formation of the values of society, being apprehended the normative contexts, 
each nation will have greater ease in achieving the objectives undertaken in relation to the protection of fundamental rights, freedoms and release paths necessary for the total development.

\section{CONCLUSION}

The climate changes that have occurred in recent years, as a result of global warming due to the increase in the emission of greenhouse effect gases, drew the attention of governments around the world, in view of the already aware possibility of occurrence of situations, for example: the increase in the level of the oceans; the emergence and growth of deserts; the imbalance in ecosystems, resulting in new pests and diseases; the increase of hurricanes, typhoons and cyclones; heat waves, and the melting of permafrost, permanently frozen soils of the Arctic region.

The research was conducted with the objective of verifying the way in which nations can contribute to the realization of carbon neutralization measures, capable of reducing the effects of global warming, considering that stems from a complex set of measures and possible actions, through legislative and implementation which are essential to protect the fundamental right to ecologically balanced environment and integral development.

The harmful effect of global warming depends on the adoption of a set of actions able to assist in its desideratum, such as the use of clean and sustainable energy, and the carbon neutralization.

For its effective implementation, legal mechanisms were created, with emphasis on the Kyoto Protocol and the prediction of the Clean Development Mechanism, as well as the Paris Agreement, which gives all participating countries, the possibility to establish emission reduction targets for greenhouse gas emissions.

Between opposing and favorable positions, the reality is that the deployment of Clean Development Mechanisms, brought by the Kyoto Protocol, provided stimuli for the realization of the carbon neutralization. The 8,157 registered projects registered so far show that the developing countries are resorting to these mechanisms which, consequently, results in the flow of capital to invest in development, as well as the carbon neutralization through reforestation and use of clean energies.

Only the rules outlined by the Kyoto Protocol were not enough to achieve the global climate targets, for which reason the Paris Agreement shall impose obligations to reduce carbon emissions for all signatory countries, so that each one within the reasonableness, establishes their own goals to be pursued.

The Paris Agreement's leaving, announced by the United States, in addition to causing negative impacts to the achievement of the objectives of climate, puts a vacuum in the leadership that the country has built in climate negotiations, so that the world climate may become even more misruled.

Many are the difficulties to brake global warming, now potentiated by the lack of commitment of the Member States before this cause, which became even more evident the importance of awareness and participation of the population, pointing as one of the ways to the success a scenario of construction of social values that encompasses the need of carbon neutralization.

The adjustment of the climatic conditions of the planet does not cover only the leaders of States to sign international agreements, but especially the participation of the population of each one of them.

The public policies of each Member State must be in harmony with the values of its citizens, doing what their responsibilities are from the freedom given to each one; such policies, together with the education, provide them with real conditions of freedom, both substantive and instrumental. 
In the wake of this understanding, the goal of the research achieved success, to the extent that identified the importance of the involvement of individuals and of nations, to contribute to the realization of possible measures to provide the carbon neutralization, emphasizing that, therefore, public policies should result in responsibilities to everybody, so as to provide development and freedom, in alignment with the values of each one, which must be redeemed through education.

The theory of development as freedom, which takes into account the education for purposes of political, economic and social development, giving the necessary freedom for individuals to participate in the formation of the society values, has relevant principles to make believe that their application can provide solutions to the achievement of the goals of reducing greenhouse gases, thus ensuring decent conditions of life for future generations, through a process of dynamogenesis that ensures the integral development, financially viable, socially fair and environmentally responsible.

Finally, the research made it clear the need for a process of dynamogenesis, driven by the development as freedom, in tune with the public policies and values of each citizen, to achieve the necessary reduction of greenhouse gases.

\section{REFERENCES}

AOSIS.ORG. Alliance of Small Islands States, 2017. Disponível em: <http://aosis.org/pressrelease-deadly-hurricanes-raise-stakes-at-first-island-cop/>. Acesso em: 12 nov. 2017.

APP - Alianças Público Privadas. Mecanismo de desenvolvimento limpo programático: uma oportunidade para alianças público-privadas. Rio de Janeiro: IBAM; Fomin/BID, 2014.

Disponível em: <http://www.aliancaspublicoprivadas.org.br/app/wpcontent/uploads/2014/07/08txt-mdl-v.editada.pdf>. Acesso em: 02 nov. 2017.

ARAÚJO, Antonio Carlos Porto. Como Comercializar Créditos de Carbono. São Paulo: Trevisan Editora Universitária, 2006.

ARMADA, Charles Alexandre Souza, BINOTTO, Daniela Regges. Mudanças climáticas no cenário internacional: antecedentes da COP 21 e perspectivas futuras. In Direito e sustentabilidade na era do antropoceno: retrocesso ambiental, balanço e perspectias, volume 2, São Paulo: 22o Congresso Brasileitoro de Direito Ambiental, 2016, p. 92. Disponível em: <http://www.planetaverde.org/arquivos/biblioteca/arquivo_20170605180403_5952.pdf>.Acesso em: 26 ago. 2017.

BARBOSA, Vanessa. COP 23 - o que avançou (ou não) na reunião de clima da ONU. Revista Exame.com. Disponível em: <https://exame.abril.com.br/mundo/cop23-principais-resultados-dareuniao-de-clima-da-onu-em-bonn/> . Acesso em 19 nov. 2017.

BRASIL. Constituição da República Federativa do Brasil de 1988. Disponível em: <http://www.planalto.gov.br/ccivil_03/constituicao/constituicaocompilado.htm>. Acesso em: 28 ago. 2017.

BRASIL. Decreto Legislativo $n^{\circ} 144$, de 2002. Aprova o texto do Protocolo de Quioto. Disponível em: <http://www2.camara.leg.br/legin/fed/decleg/2002/decretolegislativo-144-20junho-2002-458772-protocolo-1-pl.html>. Acesso em: 02 out. 2018.

BRASIL. Decreto $n^{\circ} 5.445$ de 12 de maio de 2005. Disponível em: <http://www.planalto.gov.br/ccivil_03/_Ato2004-2006/2005/Decreto/D5445.htm >. Acesso em: 
28 ago. 2017.

BRASIL. Lei Ordinária $n^{\circ} 6.938$ de 31 de agosto de 1981. Disponível em:

<http://www.planalto.gov.br/ccivil_03/leis/L6938.htm>. Acesso em: 28 ago. de 2017.

BRASIL. Lei Ordinária $n^{o} 10.203$ de 22 de fevereiro de 2001. Disponível em:

<http://www.planalto.gov.br/ccivil_03/leis/LEIS_2001/L10203.htm>. Acesso em: 28 ago. 2017.

BRASIL. Lei Ordinária no 12.187 de 29 de dezembro de 2009. Disponível em:

<http://www.planalto.gov.br/ccivil_03/_ato2007-2010/2009/lei/112187.htm>. Acesso em: 02 nov. 2017.

BRASIL. Governo Federal. Portal Brasil. Saiba mais sobre o Protocolo de Quioto. Disponível em: <http://www.brasil.gov.br/meio-ambiente/2010/11/protocolo-de-quioto>, 2010. Acesso em: 28 ago. 2017.

BRASIL. Governo Federal. COP-22 inicia regulamentação sobre o Acordo de Paris. Disponível em: <http://www.brasil.gov.br/meio-ambiente/2016/11/cop-22-inicia-regulamentacao-do-acordode-paris>, 2016. Acesso em: 30 ago. 2017.

BRASIL. Instituto Brasileiro de Defesa da Natureza - IBDN. Neutralização de carbono: descubra o que é e qual a importância desse processo. Disponível em:

<http://www.ibdn.org.br/2017/07/12/neutralizacao-de-carbono-descubra-o-que-e-e-qualimportancia-deste-processo/>, 2017. Acesso em: 25 ago. 2017.

CALIXTO, Bruno. Trump sai do Acordo de Paris: Ruim para o planeta, pior para os EUA. Revista Eletrônica Época, 2017. Diponível em: <http://epoca.globo.com/ciencia-e-meioambiente/blog-do-planeta/noticia/2017/06/trump-sai-do-acordo-de-paris-ruim-para-o-planetapior-para-os-eua.html>. Acesso em: 02 nov. 2017.

CALLETI, Leandro; STAFFEN, Márcio Ricardo. Da necessidade de uma universalidade rediviva para os direitos humanos. Revista de Direito Brasileira. São Paulo-SP. V. 16, n. 7, p. 96-114, jan/abr. 2017.

CAMPELLO, Lívia. G. B.; SILVEIRA, Vladimir O. Educação para o desenvolvimento sustentável (EDS) e o greening das universidades. Revista Thesis Juris - RTJ, eISSN 23173580, São Paulo, V. 5, N.2, pp. 549-572, Mai.-Ago. 2016

CASARA, Ana Cristina. Direito ambiental do clima e créditos de carbono. Curitiba: Juruá, 2009.

COP-23.ORG. Sustainable Innovation Forum 2017. Disponível em: <http://www.cop23.org/about/cop23/>. Acesso em: 12 nov. 2017.

DAINEZI, Adriana Fernandes et all. Adicionalidade em Projetos de MDL. Revista Magister de Direito Ambiental e Urbanístico, Porto Alegre: Magister, n. 38: p. 60-73, out-nov. 2011. Disponível em: <https://bdjur.tjdft.jus.br/xmlui/handle/123456789/8998>. Acesso em: 03 set. 2017.

DERANI, Cristiane. Direito Ambiental Internacional. São Paulo: Max Limonade, 1997. 
DIAS, Reinaldo. Gestão ambiental: responsabilidade social e sustentabilidade. São Paulo: Atlas, 2008.

DUTSCHKE, Michael. O Brasil como ator no processo da política climática. Cadernos do Instituto de Estudos Avançados da Universidade de São Paulo. São Paulo: outubro de 2000.

Disponível em: http://home.wtal.de/dutschke/Publications/O_Brasil_como_ator.PDF. Acesso em: 02 nov. 2017.

FELIPETTO, Adriana Vilela Montenegro. Mecanismos de desenvolvimento limpo aplicado a resíduos sólidos: conceito, planejamento e oportunidades. Rio de Janeiro: IBAM, 2007.

Disponível em:

<http://www.mma.gov.br/estruturas/srhu_urbano/_publicacao/125_publicacao12032009023847>. Acesso em 03 set. 2017.

FIORILLO, Celso Antonio Pacheco. Curso de Direito Ambiental Brasileiro. São Paulo: Saraiva, 2005.

HOBBES, Thomas. Leviatã ou matéria, forma e poder de um Estado eclesiástico e civil. São Paulo: Editora Nova Cultural, 2000.

HOMEM, António Pedro Barbas. História das Relações Internacionais: o Direito e as concepções políticas na Idade Moderna. Coimbra: Almedina, 2003.

IPCC - Intergovernmental Panel on Climate Change. Renewable energy sources and climate change mitigation: Summary for policymakers and technical summary. Special report of the intergovernmental panel on climate change. Disponível em: <https://www.ipcc.ch/pdf/specialreports/srren/SRREN_FD_SPM_final.pdf>. Acesso em: 24 ago. 2017.

LIMIRO, Danielle. Crédito de carbono. Curitiba: Juruá, 2009.

MESSIAS, Ewerton Ricardo; SOUZA, Paulo Roberto Pereira. Financiamento e dano ambiental: a responsabilidade civil das instituições financeiras. Rio de Janeiro: Lumen Juris, 2015.

MILARÉ, Édis. Direito do ambiente: doutrina, prática, jurisprudência, glossário. São Paulo: Revista dos Tribunais, 2005.

ONU - Organização das Nações Unidas. Declaração do Rio sobre Meio Ambiente e Desenvolvimento. Disponível em: <http://www.onu.org.br/rio20/img/2012/01/rio92.pdf>, 1992. Acesso em: 12 set. 2017.

PEREIRA, Marcilene Alves Lombardo. Aquecimento global: sequestro de carbono. Disponível em: <http://www.avm.edu.br/docpdf/monografias_publicadas/K210888.pdf>, 2009. Acesso em: 27 ago. 2017.

POPOVICH, Nadja; SCHLOSSBERG, Tatiana. 23 environmental rules rolled back in Trump's first 100 days. New York: The New York Times, 2017. Disponível em:

<https://www.nytimes.com/interactive/2017/05/02/climate/environmental-rules-reversed-trump100-days.html?_r=3>. Acesso em: 02 nov. 2017. 
RAMSEUR, Jonathan L. The Role of Offsets in a Greenhouse Gas Emissions Cap-and-Trade Program: Potential Benefits and Concerns. CRS Report for Congress, 2008. Disponível em: <http://nationalaglawcenter.org/wp-content/uploads/assets/crs/RL34436.pdf>. Acesso em: 27 ago. 2017.

REZEK, José Francisco. Direito internacional público. São Paulo: Saraiva, 1996.

SANTIAGO, R. S.; CAMPELLO, L. G.; ANDRADE, S. L. A valorização da identidade cultural como desafio à concretização do direito ao desenvolvimento. Revista de Direito Brasileira. São Paulo-SP. V. 19, n. 8, p. 3-19, jan/abr. 2018.

SEN, Amartya. Desenvolvimento como liberdade. São Paulo: Companhia das Letras, 2010.

SILVEIRA, Vladmir Oliveira; FERNANDES, A. C. S. O Direito ao Desenvolvimento Integral em face da Política Nacional de Resíduos Sólidos. Revista Jurídica-Unicuritiba, v. 1, p. 46-61, 2017.

SILVEIRA, Vladmir Oliveira; ROCASOLANO, Maria Mendez. Direitos Humanos: Conceitos, Significados e Funções. São Paulo: Editora Saraiva, 2010.

UNFCC - United Nations Framework Convention on Climate Change. Disponível em: <http://cdm.unfccc.int/>. Acesso em: 02 nov. 2017.

VENTURA, Andréa Cardoso. Mecanismo de desenvolvimento limpo (MDL): uma análise da regulação de conflitos socioambientais do projeto plantar. Dissertação (mestrado) - Universidade Federal da Bahia: Salvador, 2008. Disponível em:

<http://www.adm.ufba.br/sites/default/files/publicacao/arquivo/dissertaca_andrea_ventura.pdf >. Acesso em: 02 nov. 2017.

VIDAL, Samuel. Controlando o aquecimento global: como reduzir em $30 \%$ as emissões de gases estufa até 2030. Disponível em:

$<$ http://www.cairu.br/biblioteca/arquivos/Meio_ambiente/Controlando_aquecimento\%20global.p df>. Acesso em: 25 ago. 2017. 